\title{
Explaining the European Parliament's Legislative Clout
}

Citation for published version (APA):

Mahr, E., \& Ringe, N. (2016). Explaining the European Parliament's Legislative Clout: The Individual-Level Determinants of EP Bargaining Success. Zeitschrift für Politikwissenschaft, 26(1), 25-47.

https://doi.org/10.1007/s41358-016-0021-8

Document status and date:

Published: 01/03/2016

DOI:

10.1007/s41358-016-0021-8

Document Version:

Publisher's PDF, also known as Version of record

\section{Please check the document version of this publication:}

- A submitted manuscript is the version of the article upon submission and before peer-review. There can be important differences between the submitted version and the official published version of record.

People interested in the research are advised to contact the author for the final version of the publication, or visit the DOI to the publisher's website.

- The final author version and the galley proof are versions of the publication after peer review.

- The final published version features the final layout of the paper including the volume, issue and page numbers.

Link to publication

\footnotetext{
General rights rights.

- You may freely distribute the URL identifying the publication in the public portal. please follow below link for the End User Agreement:

www.umlib.nl/taverne-license

Take down policy

If you believe that this document breaches copyright please contact us at:

repository@maastrichtuniversity.nl

providing details and we will investigate your claim
}

Copyright and moral rights for the publications made accessible in the public portal are retained by the authors and/or other copyright owners and it is a condition of accessing publications that users recognise and abide by the legal requirements associated with these

- Users may download and print one copy of any publication from the public portal for the purpose of private study or research.

- You may not further distribute the material or use it for any profit-making activity or commercial gain

If the publication is distributed under the terms of Article $25 \mathrm{fa}$ of the Dutch Copyright Act, indicated by the "Taverne" license above, 


\title{
Explaining the European Parliament's Legislative Clout
}

\section{The Individual-Level Determinants of EP Bargaining Success}

\author{
Ewa Mahr • Nils Ringe
}

Published online: 11 April 2016

(C) The Author(s) 2016. This article is available at SpringerLink with Open Access

\begin{abstract}
This article investigates which factors shape the European Parliament's (EP) bargaining success under the codecision procedure, focusing on three sets of predictors that operate at the levels of the rapporteur and the responsible EP committee: ideological distances to the Council of Ministers, qualifications of MEPs, and institutional factors. Our results indicate that greater ideological distance between EP delegates and the Council depresses bargaining success; that inter-institutional contestation becomes more focused on the left-right dimension over time; that several factors that one might expect to benefit EP bargaining success in fact show a negative correlation; and that rapporteur-level variables are the most important predictors during the 1999-2004 EP term, while committee-level predictors matter from 2004-2009 - a difference we ascribe to successively greater oversight of rapporteurs by their parent committees.
\end{abstract}

The online version of this article (DOI:10.1007/s41358-016-0021-8) contains supplementary material, which is available to authorized users.

Ph.D. student E. Mahr $(\bowtie)$

Faculty of Arts and Social Sciences, Brussels Campus, Maastricht University

Avenue de l'Armée 10, 1040 Brussels, Belgium

e-mail: e.mahr@maastrichtuniversity.nl

Associate Prof. N. Ringe

Department of Political Science, University of Wisconsin-Madison

201B North Hall, 1050 Bascom Mall Madison Wisconsin, 53706, United States of America

e-mail: ringe@wisc.edu 


\section{Der legislative Einfluss des Europaparlaments}

Verhandlungsführer und Verhandlungserfolg

Zusammenfassung Dieser Artikel untersucht, welche Faktoren den Verhandlungserfolg des Europaparlaments (EP) im Mitentscheidungsverfahren der Europäischen Union beeinflussen. Wir betrachten insbesondere individuelle Eigenschaften der Berichterstatter und kollektive Eigenschaften der Mitglieder des zuständigen Ausschusses: ideologische Distanz zum Rat der Europäischen Union, die Qualifikationen der EP-Delegierten, sowie verschiedene institutionelle Faktoren. Unsere Analysen belegen, dass die ideologische Distanz zwischen EP-Delegierten und Rat den Verhandlungserfolg des EP reduziert; dass sich im Zeitverlauf interinstitutionelle Kontroversen vermehrt auf die Links-Rechts-Dimension fokussieren; und dass verschiedene Faktoren, die erwartungsgemäß positiven Einfluss auf den Verhandlungserfolg des EP zeigen sollten, diesen tatsächlich vermindern. Außerdem wird deutlich, dass Eigenschaften der Berichterstatter während der Legislaturperiode 1999-2004 den größten Einfluss auf den Verhandlungserfolg des EP hatten, während dies in der Legislaturperiode 2004-2009 für die Mitglieder des zuständigen Ausschusses galt. Diese Unterschiede schreiben wir der größeren Kontrolle der Berichterstatter durch ihre Ausschusskollegen zu.

\section{Introduction}

This article contributes to the growing literature on inter-institutional bargaining in European Union (EU) law-making by evaluating which factors impact the bargaining success of the European Parliament (EP) in its negotiations with the Council of Ministers. Our focus is on the extent to which the attributes of actors to whom the EP has delegated decision-making authority, namely the rapporteur (the EP's main negotiator in its bicameral bargaining with the Council of Ministers) and the members of the responsible EP committee, affect the proportion of amendments put forward by the EP that are accepted by the Council. We argue that such individuallevel effects are likely because subgroups of delegates representing the EP vary in the extent to which they are representative of the chamber as a whole; because delegates may pursue outcomes that are objectively more or less acceptable to the Council; and because EP delegates may be perceived as more or less radical, accommodating, and trustworthy by their Council counterparts.

We use a newly coded dataset composed of amendment data for all EU legislation under the codecision procedure (today called the "ordinary legislative procedure") ${ }^{1}$, which gives the EP the power of both amendment and veto and makes it an equal partner of the Council of Ministers, during the EP's fifth (1999-2004, or EP5) and sixth legislative terms (2004-2009, or EP6). We determine EP bargaining success in an innovative fashion, in that we weight different categories of acceptance by the Council; that is, we take into account if the Council accepts EP amendments "in

\footnotetext{
${ }^{1}$ We refer to "codecision" throughout, since that is what the procedure was called for the period of time covered by our data.
} 
full", "in part", or "in principle". For reasons outlined below, we exclude instances of where the bargain between EP and Council was the result of informal compromise prior to first or second reading (often referred to as "early agreements"). Our findings and conclusions, therefore, only apply to instances where the codecision procedure took its regular course.

Our analyses focus broadly on three sets of predictors that operate at the levels of the rapporteur and the responsible EP committee: ideological distances to the Council of Ministers, individual attributes and qualifications of MEPs, and institutional factors. The results of our fractional logit model indicate that greater ideological distance between EP delegates and the Council decreases bargaining success; that inter-institutional contestation becomes more focused on the left-right dimension over time; that several factors that one might expect to benefit EP bargaining success in fact show a negative correlation; and that rapporteur-level variables are the most important predictors during EP5, while committee-level predictors matter in EP6. We ascribe this difference to successively greater oversight of rapporteurs by their parent committees.

We contribute to a growing body of research that examines patterns of bicameral bargaining in the EU, by investigating how the EP's main delegates in its inter-institutional negotiations with the Council help shape legislative outcomes. As such, our article helps explain under what circumstances the directly elected representatives of EU citizens achieve their collective goals, which has important consequences for the quality of democratic representation in the EU. We also make a general contribution to the study of bicameral legislatures by examining how key individuals affect bargaining outcomes.

The article proceeds by first discussing the reasons why we expect the attributes of individual EP delegates to impact the EP's bargaining success in EU lawmaking. We then introduce three sets of hypotheses about the impact of ideological, individual, and institutional factors on bargaining success, and we discuss why we expect there to be variation across EP terms in terms of who matters in the bargaining process. After describing our data and the operationalization of our variables, we present and summarize the results of our fractional logit model. The final section concludes.

\section{Key negotiators and EP bargaining success}

Our article is part of a set of research on the inter-institutional dynamics of EU lawmaking (e.g. Rasmussen 2005; Thomson et al. 2006; König et al. 2007; Costello and Thomson 2011, 2013; Høyland and Hagemann 2010; Häge 2011; Finke 2012). It investigates if and how the individual-level attributes of those MEPs to whom the $\mathrm{EP}$ as a whole has delegated decision-making authority affect the EP's bargaining success in its negotiations with the Council of Ministers. To date, this question has only been addressed in relation to EP's rapporteurs (i. e., those members of the responsible committee charged with drafting the EP's official reports on specific policy proposals, shepherding a piece of legislation through the lawmaking process, and serving as the EP's main negotiator with other EU institutions) and in reference to a subset of controversial issues from a limited number of legislative proposals 
(Costello and Thomson 2011). Our research shares the focus on rapporteurs, but makes additional contributions by considering the makeup of the responsible EP committee - or the subset of lawmakers to whom the parent chamber has delegated the authority to consider proposals in a particular policy area ${ }^{2}-$ and by expanding the analysis to a broader set of legislative proposals.

We ask a simple but important question: does it matter who represents the EP in its negotiations with the Council? There are several good reasons to expect that it does. First, we know that the distribution of rapporteurships in the EP is a strategic process and that not all rapporteurs perfectly represent the median legislator (Costello and Thomson 2011, 338-9). Similarly, even though EP committees have been found to be fairly representative of the EP median (McElroy 2006; Yordanova 2009), there is still substantial variation in their distance to the Council median. ${ }^{3}$ Moreover, there is also variation in delegate attributes beyond their ideological dispositions, which may impact the EP's bargaining success, such as their experience, expertise, or party affiliation. Second, different EP negotiators may pursue bargaining outcomes that are, objectively, more or less acceptable to the Council. On the one hand, this may be because some EP delegates shape the EP's bargaining position in the intraparliamentary decision-making process,${ }^{4}$ by steering the EP as a whole to take more "extreme" positions relative to the Council. On the other hand, some EP delegates may drive a "harder bargain" with the Council, either in an effort to advance the EP's actual position by getting the Council to make greater concessions, or by pursuing their own interests rather than those of their institution.

Finally, even if it objectively did not matter who negotiates on behalf of the EP, EP delegates might be perceived differently by the Council, which may therefore be more or less inclined to accept a greater proportion of EP amendments. Perceptions of the opponent in negotiations matter in that one negotiating party may make false assumptions about the positions of their opponents or their willingness to make concessions. This tendency is driven by a lack of information about the true

\footnotetext{
2 Of course, there are subgroups of legislators in the responsible committee who closely follow particular legislative proposals and who play an active role in negotiating with the Council. These include, most importantly, so-called shadow rapporteurs (who monitor the proposal for their party groups), but also other legislators who choose to engage actively in the deliberation and negotiation of specific proposals (Ringe 2010). We focus on the committee as a whole, rather than these subgroups of committee members engaged with particular dossiers, for three reasons. First, while the EP formally delegates decision-making authority to its standing committees and rapporteurs, the subgroups are not ex officio delegates of the chamber. Second, even if not part of a given subgroup of negotiators, regular committee members play a central role at the committee stage, as they can "challenge the state of affairs and exercise control over the rapporteur by tabling amendments" (Hurka 2013, 274); it would, therefore, be misleading to discount them a priori. Third, the subgroups are quite fluid, and positively identifying their members for the large number of proposals that make up our data is not possible. We therefore concentrate on formal delegates who can be confidently identified.

${ }^{3}$ For example, using the indicator introduced below, the distance to the Council median on the left-right dimension in EP6 ranges from 0.23 for the Committee on Legal Affairs and the Internal Market to 1.12 for the Committee on Development and Cooperation, a difference of 2.55 standard deviations. The distances of EP committees from the Council median range from 0.055 to 1.05 on the left-right dimension (s.d. 0.205 ) and from 0.08 to 0.49 on the pro-/anti-EU dimension in EP5 (s.d. 0.088), and from 0.015 to 0.66 on the pro-/anti-EU dimension in EP6 (s.d. 0.066).

4 Finke (2012) concludes that the rapporteur is a primus inter pares, in this respect. Costello and Thomson (2010) also show that rapporteurs play a role in formulating the final EP position.
} 
preferences and positions of bargaining opponents and the extent to which they can be trusted. Concerning the policy positions of their opponents, negotiators have to infer them from imperfect information. For example, Council negotiators may lack information about the true positions of their EP counterparts on the subject for their negotiations and, instead, infer those preferences from their ideological positions more generally. Specifically, Council negotiators may assume that EP delegates' positions regarding specific policies are farther from the Council's if their ideological ideal points (across all issues) diverge from theirs. Actors will also place less "strategic trust" in those opponents whose general ideological preferences they assume to deviate from their own, meaning that they assume them to have less selfinterest in reciprocating cooperation (Uslaner 2002).

Hence, in the absence of information on EP delegates' actual policy position on the issue at hand, their general ideological positions, across policies, are likely used as a proxy for both their positions on the policy at hand and the extent to which they can be trusted to act cooperatively. In this scenario, the Council is making the most informed decision it can with the information it has available. Negotiation research has shown, however, that bargaining situations are also driven by negotiators' biases, which increase the likelihood that attributes of their opponents will impact outcomes independent of their actual positions and behaviors. Of particular relevance in the context at hand is that negotiators who lack information about their opponent's preferences and priorities tend to falsely assume those preferences and priorities to be either incompatible with their own (Thompson and Hrebec 1996), or even diametrically opposed. The latter tendency describes the so-called "fixed pie" assumption (de Dreu and Carnevale 2003), which leads negotiators to engage in distributive bargaining and, therefore, miss opportunities for mutually beneficial tradeoffs (Bazerman et al. 1985; Thompson and DeHarpport 1994; Thompson and Hastie 1990). ${ }^{5}$ The prevalence of this assumption is well-established: negotiation research shows that it is made by most people entering a bargaining situation (Thompson and Hastie 1990).

In sum, in situations of imperfect information, negotiators not only rely on imperfect heuristics to infer the true positions of their counterparts and the degree to which they are trustworthy, but they also have a subconscious tendency to discount the potential for agreement. Together, these two tendencies likely interact in such a way that Council negotiators are even less likely to see potential for agreement with opponents whose policy positions on the issue at hand they assume to deviate from their own. For this reason and those outlined above, it would be problematic to assume a priori that it does not matter who represents the EP in inter-institutional negotiations. We should, instead, expect there to be variation in the EP's bargaining success depending on who negotiates on the EP's behalf - even if we cannot say conclusively in the end that it is because some delegates really are taking positions that are less acceptable to the Council than others, because the Council perceives them as radical and unaccommodating, or because they drive too hard a bargain.

\footnotetext{
5 In a distributive bargaining situation, the preferences or positions of negotiators are in conflict, while negotiators in integrative bargaining seek joint gains by approaching or expanding the Pareto-optimal frontier (Walton and McKersie 1965).
} 
Following Costello and Thomson (2013, 1027), we define bargaining success as the congruence between actors' stated policy preferences and decision outcomes. We measure the concept by using an original variable that captures the degree to which the EP is successful in shaping the content of legislation. Specifically, we consider the proportion of amendments put forward by the EP that are accepted by the Council of Ministers and investigate if that proportion is positively or negatively impacted by the individual attributes of EP delegates. This conceptualization assumes that the legislative proposal as amended by the EP reveals the true preferences of the parliament, which we believe is reasonable because amendments require majority support on the EP floor in order to be included in the EP's report, and because previous research has shown that the EP's opinion is most congruent with the position of the median MEP (Costello and Thomson 2010, 230). Ultimately, therefore, "amendment data provide a good proxy of the EP's preferences as a whole" (Burns and Carter 2010, 127).

Our measure of bargaining success deviates from previous research that either looks at the success of individual EP amendments (e. g. Kreppel 1999, 2002; Tsebelis et al. 2001; Kasack 2004; Häge and Kaeding 2007) or estimates of the policy positions of key institutional actors in the EU's inter-institutional legislative process obtained from structured interviews with involved decision-makers (see especially Thomson et al. 2012 on the "Decision making in the European Union" [DEU] I and II projects). This approach has both advantages and disadvantages. Among the disadvantages of our data, for example, is that it does not account for the identity of the amendment sponsor (Finke 2012) and that it treats all amendments as equally important (see below for further discussion of this issue). Among its strengths is that it is based on a very large number of amendments $(16,939)$ from the complete population of codecision files (350) from two full legislative terms (1999-2004 and 2004-2009), and that it does not focus on controversial issues only (like the DEU data does). In the end, we do not consider our measure to be superior to possible alternatives, but we do believe that it is critical to consider important theoretical questions using different types of data.

\section{Hypotheses}

We focus on three sets of factors at both the rapporteur and committee levels to examine the individual-level determinants of EP bargaining success: ideological, professional, and institutional. In deriving our hypotheses, we consider if EP delegates possessing each of those individual-level attribute likely increases or decreases the EP's bargaining success, relative to a generic delegate who does not possess the relevant attribute.

In terms of ideology, we examine the impact of the ideological distance between rapporteur and responsible committee on the one hand and the Council on the other. These ought to be negatively associated with bargaining success, because greater ideological distance should make it less likely that the Council accepts the EP's amendments - whether or not policy differences are real or perceived. All else 
equal, we expect that greater ideological distance between EP delegates and the Council is associated with lower EP bargaining success (Hypothesis 1).

Another determinant of EP bargaining success may be the professional qualifications of EP delegates. In particular, seniority, previous experience drafting reports, and expertise should be important assets in bicameral bargaining regarding what is often highly technical legislation. We expect that greater professional qualifications of EP delegates increase the EP's bargaining success (Hypothesis 2).

Finally, institutional factors may impact the proportion of successful EP amendments, in that they may enable or constrain EP delegates. For example, rapporteurs from large EP party groups are able to unite a greater number of MEPs behind their reports (Costello and Thomson 2011, 341-2; see also Yordanova 2009; Farrell and Héritier 2004), rapporteurs with ties to actors inside the Council may have greater access to "political intelligence" about positions inside the Council, and some committees have been dealing with codecision files longer than others and, therefore, possess greater institutional experience with the procedure. We expect these institutional factors to positively impact the EP's bargaining success: a rapporteur from a large party group (Hypothesis 3a); a rapporteur who is affiliated with a national party that is represented in the Council (Hypothesis $3 b$ ); and a responsible committee that has been handling codecision files for a longer period of time (Hypothesis $3 c$ ).

We do not expect the impact of ideological, professional, and institutional attributes of EP delegates to have a uniform effect across the two terms we consider, however, because much is different between EP5 (1999-2004) and EP6 (2004-2009). Most obviously, 2004 marks the EU's "big bang" enlargement to ten new members, mostly from Central and Eastern Europe; this entailed the influx of 162 MEPs from the new member states in 2004 and an additional 35 in 2007. It is thus possible that any differences we observe between EP5 and EP6 are due to a changing population of MEPs and, by extension, a change in the population of EP delegates in its negotiations with the Council (which we seek to control for in our analyses below). But eastward enlargement is not the only possible contributor to changes we may observe across the two terms. Another is the maturing of the codecision procedure as amended in the Treaty of Amsterdam in 1999 (codecision II), which formally made the EP and equal partner of the Council. This maturation process, we suggest, entails that characteristics of the rapporteur will be more important determinants of EP bargaining success in EP5 than in EP6 (Hypothesis $4 a$ ), and that committee-level predictors will be of greater importance in EP6 than in EP5 (Hypothesis 4b). Rapporteurs likely had significant leeway to shape outcomes when the codecision II procedure was fairly new. In other words, early on there was room for substantial agency loss, either because it was not recognized or because it was considered acceptable or inevitable as the institution as a whole familiarized itself and gained experience with the procedure (Pelizzo and Stapenhurst 2012). But, over the course of time, the disproportionate influence of rapporteurs was recognized, especially in the context of early agreements between EP and Council, which empowered rapporteurs as the EP's key negotiators in interinstitutional bargaining (Shackleton and Raunio 2003; Farrell and Héritier 2004; Costello and Thomson 2010; Héritier and Reh 2012). This unintended consequence was recognized by the EP and, especially in and after 2004, "efforts have been made 
to constrain these negotiators more and more" (Toshkov and Rasmussen 2012, 9). A particular emphasis was on placed on strengthening the role of committees. For example, the 2004 "Guidelines for First and Second Reading Agreements" specified that committee amendments ought to provide the mandate for negotiation and required the rapporteur to regularly report back to the committee, and regulation was further strengthened throughout the 2004-9 EP term (Héritier and Reh 2012, 1145). While these procedural changes aimed specifically at early agreements between EP and Council, it is conceivable that they either reflected or generated awareness of rapporteurs' privileged position (Héritier and Reh 2012, 1146) in the codecision procedure more generally. Indeed, as the influence of rapporteurs has increased, they were increasingly subject to oversight by shadow rapporteurs and other committee actors (e. g., Judge and Earnshaw 2011). Moreover, exercising greater oversight on non-early agreements became easier over time, as the number of dossiers negotiated under the regular codecision procedure dropped substantially. There were, simply put, fewer dossiers and rapporteurs to monitor. For these reasons, we maintain, the role of the committee was likely strengthened over time relative to that of the rapporteur.

\section{Data and operationalization}

In testing the above expectations empirically, our unit of observation is each legislative reading in EP5 and EP6 on dossiers decided under the codecision procedure. That is, we do not look at the EP's aggregate success rate across all readings on a given proposal, but at its success rate at each legislative reading stage. Therefore, we have more than one observation for those legislative proposals that went beyond the first reading stage; specifically, we have 540 observations (399 in EP5 and 141 in EP6) from 350 legislative proposals. ${ }^{6}$

We count one observation if a proposal was decided in first reading or as an early second reading agreement (where the final agreement reflects the Council of Minister's Common Position, without further second reading amendments put forward by the Parliament) and two observations if it was decided in second reading or third reading. The following restrictions apply: first, we include only the procedures where the first reading of the Parliament took place after May 1999. Including earlier procedures would create problems with comparability of data, because for a considerable number of procedures the Parliament's first reading took place not under codecision but under the cooperation procedure. Second, the procedures where the EP did not adopt any amendments are excluded, as they do not provide any information on the bargaining success of the Parliament. Third, only amendments to legislative proposals are taken into account, and not the amendments

\footnotetext{
6 The distribution of proposals across committees ranges from 2 (Constitutional Affairs) to 190 (Environment), with an average of 32 .
} 
to the accompanying Parliament's legislative resolutions, as they are not subject to the negotiations with the Council. ${ }^{7}$

Finally, we exclude cases where the bargain between EP and Council was the result of informal compromise prior to first or second reading (Rasmussen 2011; Reh et al. 2013; Toshkov and Rasmussen 2012) ${ }^{8}$, a significant increase of which explains the divergence in the number of observations for EP5 and EP6. ${ }^{9}$ Such instances are excluded from our analyses for several reasons. First, negotiations are conducted "informally by a restricted and secluded group of representatives from EP, Council, and European Commission" and often "take place before the EP issues its formal opinion and before the Council adopts its common position" (Reh et al. 2013, 1113, 1119 [emphases in original]; see also Toshkov and Rasmussen 2012, 4). When this is the case, committees "might have played a role in shaping the substance of the agreed upon text, [but] the extent of this influence is impossible to objectively quantify" (Yordanova 2009, 5). Hence, it is not always clear which of the amendments agreed upon between EP and Council reflect the objectives of the EP, and should therefore be included in the proportion of successful EP amendments. Second, as Burns, Carter, and Worsfold point out (2012, 65), informal bargains involve amendments to which EP and Council negotiators are already committed, which means that EP amendments are generally weaker (and thus likely not an appropriate measure of the EP's actual collective will), and that the EP's adoption record is inflated because the EP's amendments are already assured the Council's support. Third, in the case of early agreements it would be problematic to assume, as we do, that the EP's report reveals the chamber's collective preference, because Costello and Thomson (2010) find that the EP's opinion under early agreements does not reflect the position of the median MEP. For these reasons, early agreements based on informal bargains between EP and Council, though surely a crucial component of the EU inter-institutional legislative process, involve a very different decisionmaking dynamic than when the regular codecision procedure takes its course.

The critical question, of course, is if there is a selection effect that may bias our results when we exclude those cases, which would be the case if the factors that predict a procedure being decided in an early agreement differed across the two terms. To test if this is the case, we ran additional logistic regression models (not reported) where we predict early agreement based on informal compromise (see also Reh et al. 2013). ${ }^{10}$ The independent variables in these models are workload

\footnotetext{
7 A very small number of procedures is excluded from the dataset due to unavailability of data, for example because the normal procedure of adopting the amendments in the plenary was not followed and it was therefore impossible to calculate the number of adopted amendments.

8 We are grateful to Christine Reh and her co-authors for sharing their early agreement data, which allowed us to identify the files to be excluded. It is important to note that their data do not exclude all procedures that are concluded early, but only those acts that were negotiated informally. To identify these particular early agreements, Reh et al. (2013) searched all first and second reading agreements for textual evidence that they were arrived at by informal compromise (see p. 1127 of their article for details).

98.5 percent of our observations in EP5 and 54.4 percent in EP6 are excluded because they are based on an informal compromise prior to first or second reading. As discussed above, our observations are legislative readings, not the dossiers themselves, which explains any deviations from the numbers of early agreements in Reh et al. (2013).

${ }_{10}$ Results are available in the online appendix.
} 
(the total number of ongoing codecision procedures during the Council presidency concluding the act); the number of years since fast-track legislation has been possible at the time of conclusion; the distance between the rapporteur and the Council median on the left-right dimension and pro-/anti-EU dimensions; whether or not the rapporteur's country is holding the Council presidency; and anticipation of an upcoming election (whether or not the procedure was concluded in less than the average duration of all dossiers before the upcoming EP election). The results are consistent across both terms: the number of years since fast-track legislation was introduced is positive and significant, while anticipation of an upcoming EP election is negative and significant. Not significant are workload, the ideological distances of the rapporteur to the Council, and whether or not the rapporteur's member state holds the Council presidency. The consistency of these results across the two terms suggests that the empirical differences we observe are not driven by a selection effect. ${ }^{11}$

\subsection{Dependent variable}

Our dependent variable is the proportion of amendments put forward by the EP that is accepted by the Council of Ministers. The Council does not always accept all the EP's amendments in full, however; it may also accept amendments "in part" or "in principle" which means that we cannot simply count amendments as accepted or rejected. Therefore, we operationalize this variable by weighting the different categories of acceptance by the Council (as identified by the Council itself in its statements of reasons for its common positions). ${ }^{12}$ We give a weight of 1 to amendments that are "fully incorporated" by the Council, 0.75 to amendments that are "fully or partly incorporated" and 0.5 to amendments that are "partly or in principle incorporated". For example, if the EP introduced 100 amendments, of which 20 were accepted by the Council in full, 50 were "fully or partly incorporated" and the remaining 30 were "partly or in principle incorporated", the value of the dependent variable for this observation would be $(20+50 * 0.75+30 * 0.5) / 100=$

\footnotetext{
11 As an additional robustness check, we also ran a linear Heckman selection model where the selection equation is equivalent to the logistic regression described above and the outcome equation to the model in Tab. 2. The results are entirely consistent with the ones we report and available in the online appendix.

12 Hurka (2013) also differentiates between different levels of amendment success. Categorizing amendments by the degree to which they are accepted is not always easy due to inconsistencies in the Council's reasons for its common positions. We tried to adhere as closely as possible to the Council's language and intent. In our categorization, the names of the categories reflect the language used (with minor differences in wording) in the Council's common positions, where amendments are usually "fully incorporated", "partly incorporated", or "incorporated in principle". We merged the latter two categories because they both capture instances where the EP's amendments are partly modified by the Council by either rejecting part of the original text of by changing its wording. This creates our joint category "partly or in principle incorporated amendments". In some common positions, however, the Council introduces an additional category: "fully or partly incorporated amendments". We adopt this as our third category, next to "fully incorporated" and "partly or in principle incorporated". Finally, in a few instances the information provided by the Council was lacking or incomplete. We double-checked such cases against EP records and made relevant adjustments by identifying and coding individual amendments left out of the Council's count in its common positions.
} 
0.725. It is important to emphasize, however, that our substantive findings are robust to various alternative specifications of the dependent variable. ${ }^{13}$

The EP's bargaining success rate is, by definition, 100 percent if a proposal is decided in first reading, since this means that the Council accepts all amendments tabled by the EP; 80 of our observations fall into the category (60 in EP5 and 20 in EP6). For the same reason, the EP's success rate is 100 percent for the second reading observations where the procedure is concluded in second reading with EP amendments; this applies to 244 of our observations (171 in EP5 and 73 in EP6). For the remaining 216 observations (168 in EP5 and 48 in EP6), the success rate is equal to or less than 100 percent, with a mean of 44.29 percent (std. dev.: 21.59). The means are 45.15 percent (std. dev.: 22.62) for EP5 and 41.28 percent (std. dev.: 17.41) for EP6. Across all three readings, including the 100 percent successful observations, the mean is 63.75 percent (std. dev.: 32.35) for the pooled data, 62.36 percent (std. dev.: 32.23) for EP5, and 67.69 percent (std. dev.: 32.49) for EP6. Tab. 1 provides descriptive statistics for all variables.

As already suggested above, there are important challenges associated with using EP amendments as a measure of bargaining success. One is that the approach takes amendments as given, when the process of drafting, proposing, and (co-)sponsoring amendments is highly political. As previous work has convincingly demonstrated (Finke 2012; Hurka 2013), the question of where individual amendments come from and how they shape the EP's collective position is exceedingly important. It is also outside the scope of this article, however.

Second, as Kreppel emphasizes, "not all amendments are created equal" (1999, 522). Hence, merely counting successful amendments may not adequately capture the extent to which the EP has achieved its political objectives. The alternative to simple counts would be careful categorization of amendments by either relative importance (Tsebelis and Kalandrakis 1999; Kasack 2004; Burns and Carter 2010; Burns et al. 2012) or type (Kreppel 1999, 2002). Such categorizations are possible and desirable under specific circumstances, but problematic in others - including ours. Burns, Carter, and Worsfold successfully categorize amendments by relative importance (2012; see also Burns and Carter 2010); however, this is predicated on a narrow focus on amendments" "level of ecological commitment and importance" (Burns and Carter 2010, 123). This is different from seeking to determine the importance of an amendment across a variety of issue areas. As the authors themselves note, an amendment may be insignificant in its environmental impact, yet of great importance in the context of another issue dimension (Burns and Carter 2010, 128), or with regard to a particular constituency. Determining the relative importance of an amendment with regard to multiple issue dimensions and constituencies is thus more challenging. Indeed, any categorization ultimately involves "arbitrary aspects"

\footnotetext{
13 As robustness checks, we varied the 0.75 weight to 0.65 and 0.85 and the 0.5 weight to 0.4 or 0.6 and considered all possible combinations of those weights. There are no substantive differences to the models we present. The results also hold when we drop all insignificant predictors for EP5 and EP6, respectively. Finally, we ran a model that assigns no weights, i.e., which counts even amendments that are partially or in principle accepted as fully accepted. Even at this extreme, the results are quite robust, as only two variables become statistically insignificant: the Council's polarization on the left-right dimension in EP5 and the committee members' previous rapporteur experience in EP6.
} 
Tab. 1 Descriptives

\begin{tabular}{|c|c|c|c|c|c|}
\hline Variable & Mean & $\begin{array}{l}\text { Std. } \\
\text { Dev }\end{array}$ & Min & Max & Data Sources \\
\hline
\end{tabular}

EP bargaining success

EP Legislative Observatory; EP public register and internal database;

$\begin{array}{lllll}\text { EP5 } & 0.623 & 0.322 & 0 & 1 \\ \text { EP6 } & 0.677 & 0.325 & 0 & 1\end{array}$

Council public register

Rapporteur: distance to

Council median, left-right dimension

EP5

EP6

$\begin{array}{llll}1.697 & 1.22 & 0.0003 & 5.285 \\ 1.581 & 0.781 & 0.242 & 5.11\end{array}$

Rapporteur: distance to

Council median, pro-/anti-

EU dimension

EP5

EP6

$\begin{array}{llll}1.614 & 1.508 & 0.003 & 6.753\end{array}$

$\begin{array}{llll}1.418 & 1.337 & 0.055 & 6.366\end{array}$

Rapporteur: years served in EP

EP5

EP6

$\begin{array}{llll}6.398 & 4.341 & 0 & 24\end{array}$

$\begin{array}{llll}7.532 & 5.395 & 1 & 24\end{array}$

Rapporteur: number of previous codecision files

EP5

$\begin{array}{llll}4.521 & 4.786 & 0 & 29\end{array}$

EP6

5.652

$7.845 \quad 0$

Rapporteur: external experience

EP5

$\begin{array}{llll}0.246 & 0.431 & 0 & 1\end{array}$

EP6

0.34

0.476

Döring and Manow (2010)

Döring and Manow (2010)

Rapporteur: affiliated with national government party

EP5

EP6

$\begin{array}{llll}0.436 & 0.497 & 0 & 1\end{array}$

$\begin{array}{lllll}0.443 & 0.499 & 0 & 1\end{array}$

Rapporteur: affiliated with large party group

EP5

EP6

0.424

0.495

0.645

0.48

$\begin{array}{ll}0 & 1 \\ 0 & 1\end{array}$

Committee: committee median distance to Council median, left-right dimension

EP5

EP6

0.761

0.184

0.055

1.052

Committee: committee median distance to Council median, pro-/anti-EU dimension

$\begin{array}{lll}0.201 & 0.231 & 1.124\end{array}$

Authors' calculations

Authors' calculations

Yoshinaka et al. (2010)

Authors' calculations

Authors' calculations

Döring and Manow (2010)

Döring and Manow (2010)

$\begin{array}{llll}0.147 & 0.069 & 0.08 & 0.49\end{array}$


Tab. 1 Descriptives (Continued)

\begin{tabular}{|c|c|c|c|c|c|}
\hline Variable & Mean & $\begin{array}{l}\text { Std. } \\
\text { Dev }\end{array}$ & Min & $\operatorname{Max}$ & Data Sources \\
\hline EP6 & 0.087 & 0.105 & 0.015 & 0.662 & \\
\hline $\begin{array}{l}\text { Committee: members' aver- } \\
\text { age tenure }\end{array}$ & & & & & Authors' calculations \\
\hline EP5 & 8.015 & 0.672 & 7.304 & 10.111 & \\
\hline $\begin{array}{l}\text { Committee: sum of mem- } \\
\text { bers' number of previous } \\
\text { codecision files }\end{array}$ & & & & & Authors' calculations \\
\hline EP5 & 34.892 & 12.776 & 6 & 48 & \\
\hline EP6 & 34.468 & 12.183 & 6 & 49 & \\
\hline $\begin{array}{l}\text { Committee: proportion } \\
\text { of members with external } \\
\text { expertise }\end{array}$ & & & & & Yoshinaka et al. (2010) \\
\hline EP5 & 0.203 & 0.129 & 0.06 & 0.482 & \\
\hline EP6 & 0.302 & 0.117 & 0.082 & 0.767 & \\
\hline $\begin{array}{l}\text { Committee: years since } \\
\text { committee's first codecision } \\
\text { file }\end{array}$ & & & & & Authors' calculations \\
\hline EP5 & 8.624 & 1.881 & 0 & 11 & \\
\hline EP6 & 12.652 & 1.938 & 4 & 16 & \\
\hline $\begin{array}{l}\text { Control variable: percent- } \\
\text { age of MEPs from new } \\
\text { member states }\end{array}$ & & & & & Authors' calculations \\
\hline EP6 & 16.106 & 3.526 & 13.85 & 32.84 & \\
\hline $\begin{array}{l}\text { Control variable: Council } \\
\text { ideological polarization, } \\
\text { left-right dimension }\end{array}$ & & & & & $\begin{array}{l}\text { Döring and Manow } \\
\text { (2010) }\end{array}$ \\
\hline EP5 & 6.813 & 0.478 & 4.322 & 7.122 & \\
\hline EP6 & 3.354 & 0.229 & 2.774 & 3.663 & \\
\hline $\begin{array}{l}\text { Control variable: total } \\
\text { number of EP amendments }\end{array}$ & & & & & Authors' calculations \\
\hline EP5 & 27.837 & 34.707 & 1 & 331 & \\
\hline EP6 & 41.56 & 49.266 & 1 & 421 & \\
\hline $\begin{array}{l}\text { Control variable: propor- } \\
\text { tion of plenary amendments }\end{array}$ & & & & & Authors' calculations \\
\hline EP5 & 0.193 & 0.303 & 0 & 1 & \\
\hline EP6 & 0.254 & 0.381 & 0 & 1 & \\
\hline $\begin{array}{l}\text { Control variable: duration } \\
\text { of the legislative process, in } \\
\text { days }\end{array}$ & & & & & Authors' calculations \\
\hline EP5 & 662.87 & 340.867 & 44 & 2610 & \\
\hline EP6 & 886.092 & 376.586 & 173 & 2610 & \\
\hline $\begin{array}{l}\text { Control variable: first read- } \\
\text { ing }\end{array}$ & & & & & Authors' calculations \\
\hline EP5 & 0.687 & 0.464 & 0 & 1 & \\
\hline EP6 & 0.532 & 0.501 & 0 & 1 & \\
\hline
\end{tabular}


(Kasack 2004, 246) or "subjective" evaluations (Burns and Carter 2010, 130). We do not believe that it is possible for an outsider to determine an amendment's relative importance across multiple issue dimensions and constituencies at the time it was being considered; for this reason, we follow Häge and Kaeding's advice that "in the absence of a clear definition of what constitutes an important provision and a method to identify these provisions a priori, the second-best solution for the remaining amendments is to treat them as being of equal importance" $(2007,350)$.

We also choose not to categorize amendments by "type" for two reasons. First, such classification likely de facto categorizes amendments by relative importance. Kreppel, for example, classifies amendments, but then uses this typology to create an ordinal ranking (1999, 526; see also Kasack 2004, 246). Second, even small and seemingly unimportant changes, for example to proposed language, can be politically highly significant. ${ }^{14}$ A positive side-effect of our choice not to classify amendments by importance or type is that we can look at a larger number of legislative procedures and amendments than previous studies have.

The third major challenge with the use of amendments as a measure of bargaining success is that they may reflect the strategic considerations of legislative actors, rather than their true preferences. For example, the EP may forego a particular amendment in anticipation of Council resistance. The introduction of amendments thus involves behavior that the researcher cannot directly observe, and similarly plagues alternative approaches, such as the DEU projects (Thomson et al. 2006; Thomson 2011). Despite this shortcoming, we ultimately agree with previous determinations that "there is no equivalent measure [to amendments] of the Parliament's collective will" (Burns and Carter 2010, 127).

\subsection{Independent variables}

We use the ideological positions of national political parties as a proxy for individuallevel ideal points on the two primary dimension of political contestation in the EP to test H1 (left-right and pro-/anti-EU) (Döring and Manow 2010). ${ }^{15}$ We rely on these data to determine the ideal points of the rapporteur and the median of the responsible committee and to calculate their respective distances to the Council median. To calculate the latter (weighted by the number of Council votes of each member state), we rely on information on the positions of the national governments that are represented in the Council, which is derived from data on the ideological positions of the parties the governments are composed of. This entails that the Council's median (and thus its distance to rapporteurs and committees) varies over time, because national elections that take place during the course of each term affect the Council's composition.

\footnotetext{
14 Kreppel notes that "many amendments may take on political significance regardless of how small the proposed change appears" (1999, 526).

15 An alternative to using party-level data would be to rely on NOMINATE scores (Hix et al. 2007). Those, however, are not available for the Council, nor would they be comparable to the EP's, which means that it would not be possible to calculate the distance between rapporteur/committee and Council using NOMINATE.
} 
To test H2, we rely, first, on three indicators designed to capture the relative experience and expertise of rapporteurs: the number of years they have served in the EP; the total number of codecision reports of which they have previously been in charge; and a dichotomous variable coded 1 for MEPs with relevant previous political, professional, or governmental experience (what we call "external expertise") in policy areas that relate to their committee's jurisdiction (see Yoshinaka et al. 2010: 467). ${ }^{16}$ At the committee level, we account for the average number of years committee members have served in the EP; the total number of codecision reports they have been in charge of in the past; and the proportion of committee members with relevant external expertise.

To capture institutional factors, we include dichotomous measures coded 1 if the rapporteur is a member of a large party group (H3a) or is associated with a national party that is represented in the Council $(\mathrm{H} 3 \mathrm{~b})$, and the number of years that have passed since the committee handled its first codecision dossier as measure of the responsible committee's institutional experience with the codecision procedure (H3c). According to $\mathrm{H} 4 \mathrm{a}$ and $\mathrm{H} 4 \mathrm{~b}$, we should expect systematic differences across EP terms as to which factors explain the EP's bargaining success. This conditional effect if accounted for by interacting each predictor with a dichotomous indicator for EP term.

In order to determine the impact of EP delegates' attributes on bargaining success controlling for the controversy of the dossier and the extent to which the plenary engages in ex post "correction" of the committee report, we control for both the duration of the legislative process ${ }^{17}$ and for the proportion of amendments that are introduced in the plenary instead of committee. In addition, we control for the total number of amendments the EP put forward and whether or not the legislative process was concluded in first reading. ${ }^{18}$ For our EP6 observations, we also include an indicator for the proportion of members of the responsible committee who are from the new member states, to account for potential consequences of the influx of MEPs from those countries. ${ }^{19}$

\footnotetext{
16 We are grateful to Gail McElroy for providing these data.

17 This variable is operationalized as the number of days between the formal start of the legislative process (the adoption of a proposal by the Commission) and the final adoption of the Council of Ministers for procedures that end in first reading and third reading and for those that end in second reading with amendments tabled by the EP. For procedures that end in second reading without amendments put forward by the EP we count the date of the EP second-reading vote as the end point of the legislative process.

18 Unlike previous studies, we choose not to include a variable to account for the relative unity of the $\mathrm{EP}$, measured in earlier studies by the majority in favor of a legislative dossier in the final committee vote. First, the final committee vote concerns the entire report, rather than the individual amendments it contains; it therefore does not indicate relative internal controversy regarding individual amendments. Second, responsible committee cohesion is likely at least a partial function of some of our independent variables. It would thus be problematic to include it as a separate predictor.

19 It would stand to reason to also include an indicator for whether or not the rapporteur is from one of the new member states. However, MEPs from the new member states were notably disadvantaged in the allocation of codecision reports (Yordanova 2011), and there are only 10 observations in our EP6 data where this applies. Given this very low number, we forego this particular variable. When included in an additional model (not reported), it does not achieve statistical significance, the model fit worsens slightly, and all other results are consistent with those we report in Tab. 2.
} 
Finally, we control for ideological divisions inside the Council, which we expect to negatively affect the likelihood that EP amendments are accepted because the Council needs a majority or unanimous vote to accept amendments put forward by the EP. To capture this factor, we calculate the Council's internal polarization on the left-right dimension by adjusting Dalton's party system polarization index (Dalton 2008) for our purposes; ${ }^{20}$ this index ranges from a value of 0 when all national governments in the Council occupy the same ideological position to 10 when all the governments are split between a dimension's two extremes. The measure is based on two elements: (a) the relative position of each national government in the Council along the left - right dimension and (b) the national governments' positions weighted by voting strength under the relevant qualified majority voting rules. Specifically, polarization is measured as:

$$
\begin{aligned}
& \mathrm{PI}=\operatorname{SQRT}\left\{\Sigma\left(\text { voting strenght }_{\mathrm{i}}\right) \times\right.
\end{aligned}
$$

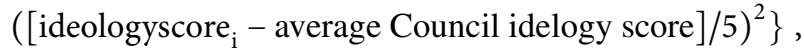

where i represents individual member states. We calculate the Council's polarization after each national election between July 1999 and June 2009.

\section{Results}

Our dependent variable is a proportion that includes values of 0 and 1 . We therefore run a fractional logit model (Baum 2008; Papke and Wooldridge 1996), the results of which are presented in Tab. 2, including marginal effects for the statistically significant predictors (which are calculated holding non-dichotomous independent variables at their means and dichotomous ones at zero). The table shows important differences across the two EP terms, which we discuss in turn.

In EP5, a greater distance between the rapporteur's position on the pro-/antiEU dimension and the Council median lowers the proportion of successful EP amendments, by 1.9 percent for a one unit increase in distance (which ranges from 0.003 to 6.753 ). Also negatively associated with bargaining success are indicators for rapporteurs with previous professional experience in policy areas related to the responsible committee's jurisdiction ( -11.2 percent) and rapporteurs from national parties that are represented in the Council ( -7.1 percent). The only independent variable that is positively associated with EP bargaining success is the rapporteur's membership in a large EP party group (+6.5 percent). Not significant are the distance of the rapporteur to the Council on the left-right dimension, seniority, and previous experience as rapporteur.

Only a single committee-level indicator achieves statistical significance in EP5, namely the proportion of members of the responsible committee with external expertise, which has a positive effect on bargaining success $(+17.9$ percent if all

${ }^{20}$ We are grateful to Holger Döring for suggesting this approach. 
Tab. 2 Results

\begin{tabular}{|c|c|c|c|c|}
\hline \multirow[b]{2}{*}{ Variable } & \multicolumn{2}{|l|}{ EP5 } & \multicolumn{2}{|l|}{ EP6 } \\
\hline & $\begin{array}{l}\text { Coefficient } \\
\text { (SE) }\end{array}$ & M. E. & $\begin{array}{l}\text { Coefficient } \\
\text { (SE) }\end{array}$ & M. E. \\
\hline \multicolumn{5}{|l|}{ Rapporteur } \\
\hline Distance to Council median, left-right & $0.009(0.069)$ & & $-0.111(0.199)$ & \\
\hline $\begin{array}{l}\text { Distance to Council median, pro-/anti- } \\
\text { EU }\end{array}$ & $\begin{array}{l}-0.137 \\
(0.061)^{*}\end{array}$ & -0.019 & $0.128(0.141)$ & \\
\hline Years in EP & $0.007(0.02)$ & & $-0.06(0.027)^{*}$ & -0.011 \\
\hline Previous rapporteur experience & $0.018(0.017)$ & & $-0.005(0.021)$ & \\
\hline External expertise & $\begin{array}{l}-0.663 \\
(0.19) * * *\end{array}$ & -0.112 & $0.07(0.242)$ & \\
\hline From government party & $\begin{array}{l}-0.449 \\
(0.166) * *\end{array}$ & -0.071 & $-0.035(0.226)$ & \\
\hline From large party group & $\begin{array}{l}0.58 \\
(0.167) * * *\end{array}$ & 0.065 & $0.5(0.227)^{*}$ & 0.081 \\
\hline \multicolumn{5}{|l|}{ Committee } \\
\hline Distance to Council median, left-right & $0.101(0.452)$ & & $-2.087(0.886)^{*}$ & -0.386 \\
\hline $\begin{array}{l}\text { Distance to Council median, pro-/anti- } \\
\text { EU }\end{array}$ & $-0.959(1.345)$ & & $-2.342(1.581)$ & \\
\hline Members' average years in EP & $0.179(0.117)$ & & $0.214(0.499)$ & \\
\hline $\begin{array}{l}\text { Members' previous rapporteur experi- } \\
\text { ence }\end{array}$ & $-0.002(0.002)$ & & $-0.008(0.004) \dagger$ & -0.002 \\
\hline Members' external expertise & $1.297(0.668)^{*}$ & 0.179 & $3.052(1.031)^{* *}$ & 0.565 \\
\hline $\begin{array}{l}\text { Years since committee's first codeci- } \\
\text { sion }\end{array}$ & $0.031(0.052)$ & & $-0.338(0.13) * *$ & -0.063 \\
\hline \multicolumn{5}{|l|}{ Controls } \\
\hline $\begin{array}{l}\% \text { new member state committee mem- } \\
\text { bers }\end{array}$ & & & $\begin{array}{l}-0.128 \\
(0.042) * *\end{array}$ & -0.024 \\
\hline Council polarization, left-right & $\begin{array}{l}-0.297 \\
(0.157) \dagger\end{array}$ & -0.041 & $0.102(0.865)$ & \\
\hline \# of EP amendments & $\begin{array}{l}-0.005 \\
(0.002)^{* *}\end{array}$ & -0.001 & $\begin{array}{l}-0.005 \\
(0.002)^{* *}\end{array}$ & -0.001 \\
\hline$\%$ of plenary amendments & $\begin{array}{l}1.509 \\
(0.355) * * *\end{array}$ & 0.208 & $\begin{array}{l}4.209 \\
(0.638) * * *\end{array}$ & 0.779 \\
\hline Duration & $-0.001(0) * *$ & -0.0002 & $\begin{array}{l}-0.002 \\
(0.0004) * * *\end{array}$ & -0.0003 \\
\hline First reading & $\begin{array}{l}-1.185 \\
(0.19) * * *\end{array}$ & -0.228 & $\begin{array}{l}-1.532 \\
(0.294) * * *\end{array}$ & -0.274 \\
\hline Constant & $2.805(1.563)$ & & $9.268(6.439)$ & \\
\hline AIC & 0.968 & & & \\
\hline $\mathrm{BIC}$ & -2610.92 & & & \\
\hline $\mathrm{N}$ & 486 & & & \\
\hline Log pseudo-likelihood & -197 & & & \\
\hline
\end{tabular}

Entries are fractional logit coefficients with standard errors clustered on legislative procedure in parentheses. Statistical significance is indicated as: ***p $<0.001 ; * * \mathrm{p}<0.01 ; * \mathrm{p}<0.05 ; \dagger \mathrm{p}<0.06$. The table does not show coefficients for the interaction terms themselves, but calculations of the coefficients and standard errors for relevant constitutive terms when EP5 $=0$ and EP5 $=1$. Marginal effects are calculated with dichotomous variables held constant at 0 and all others at their means (for observations within the respective EP term). 
committee members, as opposed to none, have previous external expertise). All five control variables are significant, however, and all but one are negatively associated with bargaining success: greater ideological polarization of the Council ( -4.1 percent for a one unit increase in polarization, which ranges from 4.322 to 7.122), a greater number of total amendments introduced $(-0.1$ percent for each additional amendment introduced); longer duration of the legislative process $(-0.02$ percent for each additional day the legislative process lasts); and observations in first reading $(-22.8$ percent fewer amendments are accepted in first reading relative to second or third readings). Bargaining success is greater, however, when a larger percentage of all EP amendments is introduced in the plenary, as opposed to in committee (bargaining success is greater by 20.8 percent if all amendments, as opposed to none, are introduced in plenary). This finding suggests that the Council does indeed care about who represents the EP, because it is more likely to see amendments that come from the plenary as representative of the true preferences of the chamber and, therefore, to accept them.

Our results for EP6 are quite different. Only two rapporteur variables are statistically significant in EP6, down from four in EP5. We again find that having a rapporteur affiliated with a large party group has a positive effect on EP bargaining success $(+8.1$ percent). However, the effect of the rapporteur's tenure in the EP is negative ( -1.1 percent for each additional year served). But in contrast to EP5, where only a single committee-level variable predicts bargaining success, four of six do so in EP6 (only seniority and distance on the pro-/anti-EU dimension are statistically insignificant). The first relates to ideological distance between Council and EP committee, where greater distance between the committee median and the Council median on the left-right dimension is negatively associated with bargaining success ( -38.6 percent for a one unit increase in distance, which ranges from 0.23 to 1.124). Three other variables that aggregate individual-level characteristics of members of the responsible committee are also statistically significant predictors of bargaining success. A greater proportion of committee members with external expertise has a positive effect $(+56.5$ percent if all members, as opposed to none, have relevant previous experience), while the effects of aggregate previous rapporteur experience of committee members ( -0.2 percent for each additional report drafted) and the number of years that have passed since the committee's first codecision file (-6.3 percent for each additional year) are negative.

While one predictor (Council polarization) no longer achieves statistical significance, perhaps because left-right polarization in EP6 is lower (at 3.35) than in EP5 (at 6.81), several other control variables perform similarly as in EP5 (total number of amendments introduced, duration of the legislative process, as well as the first reading dummy). The one control variable we added is also significant, in that a greater proportion of committee members from the new member states depresses the proportion of successful amendments, by 2.4 percent for each percent increase in their number (which ranges from 13.85 percent to 32.84 percent). There is, in other words, a negative impact of an influx of MEPs from new member states on EP bargaining success. Finally, it is notable that the effect of the proportion of plenary amendments is much greater in EP6 than in EP5: bargaining success is 77.9 percent greater if all amendments, as opposed to none, are introduced in plenary. This, in 
addition to the greater overall proportion of plenary amendments (25.4 percent in EP6 compared to 19.3 in EP5), suggests that the EP seems to take greater advantage of its power to introduce amendments to the committee report or to discard committee amendments; in other words, it may be indicative of the steps being taken at the plenary stage of the legislative process to "correct" committee reports that deviate from the EP's preferred position. ${ }^{21}$

In sum, our findings confirm $\mathrm{H} 1$, in that greater ideological distances from the Council median of the rapporteur (in EP5) and the committee (in EP6) depress bargaining success. Yet, it is notable that it is the pro-/anti-EU dimension in EP5 and the left-right dimension in EP6 that matters, ${ }^{22}$ which may suggest that political contestation is becoming "normal" not just inside the EP, but also inter-institutionally. In contrast, $\mathrm{H} 2$ is generally not supported, in that only the collective external expertise of members of the responsible committee is positively associated with bargaining success, in both EP5 and EP6. Otherwise, indicators for the professional qualifications of the EP delegates are either not significant or their impact on bargaining success is negative. We find support for $\mathrm{H} 3 \mathrm{a}$ : having rapporteurs from large party groups is positively associated with bargaining success. Neither H3b nor H3c find support, however, as the coefficients for rapporteurs from government parties and responsible committees with longer institutional histories of using the codecision procedure are either insignificant or negative. Finally, as the above discussion of our results demonstrates, $\mathrm{H} 4 \mathrm{a}$ and $\mathrm{H} 4 \mathrm{~b}$ are corroborated in our analyses: in general, rapporteur-level indicators help explain bargaining success in EP5 and committeelevel variables in EP6.

It is notable and worthy of attention in future research, however, that a variety of factors one would expect to be assets in the EP's negotiation with the Council in fact depress bargaining success. In EP5, greater external expertise of rapporteur is negatively associated with bargaining success, as is having a rapporteur from a national government party. In EP6, greater seniority of the rapporteur, committee members' previous rapporteur experience, and the institutional experience of the responsible committee with the codecision procedure all have negative effects. What these results suggest is that rapporteurs and committees with greater experience and expertise, and rapporteurs with contacts in the Council, may be overly ambitious in trying to force concessions from the Council - a strategy that ultimately backfires. This interpretation would be consistent with previous negotiation research, which has found that overconfident subjects exhibit less concessionary behaviors and perform less successfully than realistically confident ones (Neale and Bazerman 1985).

\footnotetext{
21 While Costello and Thomson (2011) hypothesize that the EP's bargaining success will be lower when the plenary amends the rapporteur's report, their analyses of data on controversial issues produce evidence to the contrary.

22 This finding adds important nuance to Costello and Thomson's (2011) conclusion that the ideological extremity of the rapporteur depresses the bargaining success for the EP.
} 


\section{Conclusion}

This article adds to our understanding of legislative politics by demonstrating empirically that the characteristics of key individuals may affect legislative outcomes. It contributes, in particular, to the study of EU lawmaking by investigating the individual-level determinants of EP bargaining success when the codecision procedure takes its regular course (that is, when the bargain between EP and Council is not the result of informal compromise prior to first or second reading). While the influence of rapporteurs is well-recognized, much remains to be learned about how attributes of other individuals can help shape policy-making processes and outcomes, in our case the members of the responsible EP committee. Our analysis provides one step in this direction.

Our results show that the ideological profile of EP delegates helps explain the EP's bargaining success, in that the rapporteur's distance to the Council on the pro/anti-EU divide in EP5 and the committee's distance to the Council on the left-right dimension in EP6 are negatively associated with the proportion of EP amendments accepted by the Council. The "switch" from the pro-/anti-EU to the left-right divide is notable, in that it may suggest that inter-institutional contestation becomes "normalized" over time. The results are also instructive in light of the development of the codecision procedure over time, in that they support our propositions about the relatively greater influence of rapporteurs in EP5 and of committees in EP6. We maintained that the introduction and successively greater use of early agreements between EP and Council, and the resulting empowerment of rapporteurs, triggered efforts at greater oversight of rapporteurs by the parent chamber in the case of early agreements and beyond. The results of our analyses suggest that committees may have indeed taken on this oversight function in EP6, as rapporteurs' ideological positions and personal characteristics have a much less pronounced impact on EP bargaining success when the codecision procedure takes its regular course (that is, in the absence of an early decision between Council and EP). Instead, it is committeelevel predictors that begin to matter most during this latter term, which means that members of the responsible committees seem to have collectively assumed legislative power from rapporteurs. It is still the case in EP6, however, that it matters who the EP has delegated decision-making authority to, since the composition of the responsible committee impacts the proportion of EP amendments the Council is willing to accept: four of six committee-level predictors affect bargaining success (or five of seven, if one also counts the proportion of committee members from the new member states).

These developments are generally encouraging, in the sense that they counteract the highly personalized decision-making dynamics brought about by the possibility of early agreements based on informal compromise between EP and Council. After all, early agreements are generally seen as problematic in terms of transparency, the representation of diverse interests in the EP, and the reputation of the EP as a collective democratic actor (Heritier and Reh 2012). A greater effort at oversight of rapporteurs in the case of early agreements (Heritier and Reh 2012; Toshkov and Rasmussen 2012), we observe, seems to be accompanied by a strengthening of committees when the codecision procedure takes its "normal" course, which entails 
greater parliamentary representation, transparency, and oversight. The associated cost, of course, is legislative efficiency. In the end, it is clear that the EP is still undergoing a process of balancing efficiency concerns with concerns about the quality of democratic representation.

Despite offering notable insight, our analyses also raise important questions for future research. Perhaps most importantly, our findings only tell us that individual attributes of EP delegates matter, but not how they matter. In the end, we cannot conclusively determine if bargaining success is lower because some EP delegates pursue outcomes that are objectively less acceptable to the Council (although Costello and Thomson conclude that rapporteurs do not seem to advocate positions that deviate from the EP outcomes they are charged with defending $(2011,355)$ ), because they are perceived to be more radical and/or less accommodating by the Council, or because they drive harder bargains (some of our findings suggest the latter may be part of the explanation). This opens up intriguing avenues for future research. Similarly, our argument about the "maturing" of the codecision procedure over time warrants further scrutiny. Particularly instructive, in this regard, would be further explorations of the "black box" of early agreements, which are consciously excluded from our examination. Another productive future line of future questioning relates to those instances where our empirical results are not in line with expectations. In particular, many factors that we expected to be assets in the EP's negotiations with the Council depress bargaining success. Determining whether this is a generalizable pattern would be of great value in our efforts to understand bicameral politics in the EU. Finally, our analyses raise critical questions about how delegation inside the EP impacts its legislative clout. They offer a starting point for further investigating who best represents and helps realize the position of the EP in its negotiations with the Council. Under which circumstances do the directly elected representatives of EU citizens get what they collectively want? Much remains to be learned, in this regard, but our article offers a number of important insights that shed light on the dynamics of decision-making and popular representation in EU politics.

\footnotetext{
Acknowledgement We are grateful to the European Union Center of Excellence at the University of Wisconsin-Madison for supporting this research and to Gail McElroy and Christine Reh for sharing some of the data used in the analyses. We also thank Holger Döring, Deborah Larson, Anne Rasmussen, the participants of the "Beyond the Hemicyle" workshop at the University of Wisconsin-Madison, and two anonymous reviewers for their valuable comments and suggestions. Finally, we are grateful to Ray Hebestreit and Karl-Rudolf Korte for their help and support.
}

Open Access. This article is distributed under the terms of the Creative Commons Attribution 4.0 International License (http://creativecommons.org/licenses/by/4.0/), which permits unrestricted use, distribution, and reproduction in any medium, provided you give appropriate credit to the original author(s) and the source, provide a link to the Creative Commons license, and indicate if changes were made. 


\section{References}

Baum, Christopher F. 2008. Stata tip 63: Modeling proportions. The Stata Journal 8(2): 299-303.

Bazerman, Max H., Thomas Magliozzi, and Margaret A. Neale. 1985. Integrative bargaining in a competitive market. Organizational Behavior and Human Decision Processes 35: 294-313.

Burns, Charlotte, and Neil Carter. 2010. Is codecision good for the environment? Political Studies 58(1): $123-142$

Burns, Charlotte, Neil Carter, and Nicholas Worsfold. 2012. Enlargement and the environment: the changing behaviour of the European Parliament. Journal of Common Market Studies 50(1): 54-70.

Costello, Rory, and Robert Thomson. 2010. The policy impact of leadership in committees: Rapporteurs' influence on the European Parliament's opinions. European Union Politics 11(2): 219-241.

Costello, Rory, and Robert Thomson. 2011. The nexus of bicameralism: Rapporteurs' impact on decision outcomes in the European Union. European Union Politics 12(3): 337-357.

Costello, Rory, and Robert Thomson. 2013. The distribution of power among EU institutions: who wins under codecision and why? Journal of European Public Policy 20(7): 1025-1039.

Dalton, Russell J. 2008. The quantity and the quality of party systems: party system polarization, its measurement, and its consequences. Comparative Political Studies 41(7): 899-920.

de Dreu, Carsten K.W., and Peter J. Carnevale. 2003. Motivational bases of information processing and strategy in conflict and negotiation. Advances in Experimental Social Psychology 35: 235-291.

Döring, Holger, and Philip Manow. 2010. Parliament and Government Composition Database (Parlgov): an infrastructure for empirical information on parties, elections and governments in modern democracies. http://www.parlgov.org

Farrell, Henry, and Adrienne Héritier. 2004. Interorganizational negotiation and intraorganizational power in shared decision making. early agreements under codecision and their impact on the European Parliament and the Council. Comparative Political Studies 37(10): 1184-1212.

Finke, Daniel 2012. Proposal stage coalition-building in the European Parliament. European Union Politics 13(4): 487-512.

Häge, Frank M. 2011. Politicizing council decision-making: the effect of EP empowerment. West European Politics 34(1): 19-47.

Häge, Frank M., and Michael Kaeding. 2007. Reconsidering the european parliament's legislative influence: formal vs. informal procedures. European Integration 29(3): 341-361.

Héritier, Adrienne, and Christine Reh. 2012. Codecision and its discontents: intra-organisational politics and institutional reform in the European Parliament. West European Politics 35(5): 1134-1157.

Hix, Simon, Abdul Noury, and Roland Gerard. 2007. Democratic politics in the European Parliament. Cambridge, UK: Cambridge University Press.

Høyland, Bjørn, and Sara Hagemann. 2010. Bicameral Politics in the European Union. Journal of Common Market Studies 48(4): 811-833.

Hurka, Steffen 2013. Changing the output: The logic of amendment success in the European Parliament's ENVI Committee. European Union Politics 14(2): 273-296.

Judge, David, and David Earnshaw. 2011. Relais actors and co-decision first reading agreements in the European Parliament: the case of the advanced therapies regulation. Journal of European Public Policy 18(1): 53-71.

Kasack, Christiane 2004. The legislative impact of the European Parliament under the revised codecision procedure: environmental, public health and consumer protection policies. European Union Politics 5(2): 241-260.

König, Thomas, Lindberg Bjorn, Sandra Lechner, and Winfried Pohlmeier. 2007. Bicameral conflict resolution in the European Union: an empirical analysis of conciliation committee bargains. British Journal of Political Science 37(2): 281-312.

Kreppel, and Amie. 1999. What affects the European Parliament's legislative influence? Journal of Common Market Studies 37(3): 521-538.

Kreppel, and Amie. 2002. Moving beyond procedure. an empirical analysis of European Parliament legislative influence. Comparative Political Studies 35(7): 784-813.

McElroy, and Gail. 2006. Committee representation in the European Parliament. European Union Politics 7(1): 5-29.

Neale, Margaret A., and Max H. Bazerman. 1985. The effects of framing and negotiator overconfidence on bargaining behaviors and outcomes. Academy of Management Journal 28: 34-49.

Papke, Leslie E., and Jeffrey M. Wooldridge. 1996. Econometric methods for fractional response variables with an application to 401(K) plan participation rates. Journal of Applied Econometrics 11: 619-632. 
Pelizzo, Riccardo, and Frederick Stapenhurst. 2012. Government accountability and legislative oversight. New York: Routledge.

Rasmussen, Anne 2005. EU conciliation delegates: responsible or runaway agents? West European Politics 28(5): 1015-1034.

Rasmussen, Anne 2011. Early conclusion in bicameral bargaining: evidence from the co-decision legislative procedure of the European Union. European Union Politics 12(1): 41-64.

Reh, Christine, Adrienne Héritier, Edoardo Bressanelli, and Christel Koop. 2013. The informal politics of legislation: explaining secluded decision making in the European Union. Comparative Political Studies 46(9): 1112-1142.

Ringe, Nils 2010. Who decides, and how? Oxford: Oxford University Press.

Shackleton, Michael, and Tapio Raunio. 2003. Codecision since Amsterdam: a laboratory for institutional innovation and change. Journal of European Public Policy 10(2): 171-187.

Thomson, Robert 2011. Resolving controversy in the European Union. Cambridge: Cambridge University Press.

Thomson, Robert, Javier Arregui, Dirk Leuffen, Rory Costello, James Cross, Robin Hertz, and Thomas Jensen. 2012. A new dataset on decision-making in the European Union before and after the 2004 and 2007 enlargements (DEUII). Journal of European Public Policy 19(4): 604-622.

Thomson, Robert, Frans N. Stokman, Christopher H. Achen, and Thomas König (eds.). 2006. The European Union decides. Cambridge: Cambridge University Press.

Thompson, Leigh, and Terri DeHarpport. 1994. Social judgment, feedback, and interpersonal learning in negotiation. Organizational Behavior and Human Decision Processes 58: 328-345.

Thompson, Leigh, and Reid Hastie. 1990. Social perception in negotiation. Organizational Behavior and Human Decision Processes 47: 98-123.

Thompson, L., and Dennis Hebrec. 1996. Lose-lose agreements in interdependent decision making. Psychological Bulletin 120: 396-409.

Toshkov, Dimiter, and Anne Rasmussen. 2012. Time to Decide: The effect of early agreements on legislative duration in the EU, in: European Integration online Papers (EIoP), 16, Article 11. http://eiop.or. at/eiop/texte/2012-011a.htm Zugriff: 2012

Tsebelis, George, Christian B. Jensen, Anastassios Kalandrakis, and Amie Kreppel. 2001. Legislative procedures in the European Union: an empirical analysis. British Journal of Political Science 31(3): 573-599.

Tsebelis, G., and Anastassios Kalandrakis. 1999. The European Parliament and environmental legislation: the case of chemicals. European Journal of Political Research 36(1): 119-154.

Uslaner, Eric M. 2002. The moral foundations of trust. New York: Cambridge University Press.

Walton, Richard E., and Robert B. McKersie. 1965. A behavioral theory of labor negotiations: An analysis of a social interaction system. New York: McGraw-Hill.

Yordanova, and Nikoleta. 2009. Legislative Power of the European Parliament Committees: Plenary Adoption of Committee Reports Paper presented at the 11th Biannual Conference of the European Union Studies Association, 23-25 April 2009. Los Angeles, California: .

Yordanova, and Nikoleta. 2011. Inter-institutional rules and division of power in the European Parliament: allocation of consultation and codecision reports. West European Politics 34(1): 97-121.

Yoshinaka, Antoine, Gail McElroy, and Shaun Bowler. 2010. The appointment of rapporteurs in the European Parliament. Legislative Studies Quarterly 35(4): 457-486. 